\title{
ALTERNATIF PERANCANGAN TATA LETAK MESIN PRODUKSI DI CV. ANUGERAH SUKSES SEJAHTERA
}

\author{
Yohanes Dwi Satya Pambudi ${ }^{1}$, Indah Apriliana Sari ${ }^{2}$ \\ 1,2Teknik Industri, Fakultas Teknik \\ Universitas 45 Surabaya \\ e-mail : pambudim9@gmail.com $\underline{\text { indahaprilianasari@gmail.com }}$
}

\begin{abstract}
ABSTRAK
Tata letak mesin adalah suatu hal yang penting jika dikaitkan dengan kegiatan proses produksi di perusahaan, karena dapat meminimalkan ruang produksi yang di butuhkan. Pada penelitian iniakan menggunakan metode Algoritma Corelap, adapun sumber data yang digunakan adalah data-data primer dan sekunder dari press release. Data akan dianalisa dengan pengumpulan seluruh nilai Total Closeness Rating stasiun kerja pada lantai produksi dan melakukan perhitungan corelap dengan cara mencari nilai tertinggi. Berdasarkan analisa data yang dilakukan, diperoleh kesimpulan bahwa pada penggunaan metode Algoritma Corelap dapat meminimalkan frekuensi pemindahan barang dan mempermudah jalannya proses produksi.
\end{abstract}

Kata kunci: Algoritma Corelap, Mesin bubut, Momen Perpindahan, Tata Letak Mesin

\section{PENDAHULUAN}

Pembagian ruangan yang baik memberikan pengaruh yang signifikan pada kelancaran suatu proses produksi. Perencanaan dan perhitungan operasi yang benar dalam suatu proses produksi, sebagai contoh dalam hal pengaturan tata letak mesin dan peralatan, akan memperlancar dan membuat operasi produksi menjadi lebih maksimal.

Adapun keuntungan dari penerapan tata letak fasilitas menurut (RAJAMANI*, Singh, \& Aneja, 1996) antara lain : dapat mengurangi waktu kerja, meminimalkan kecelakaan kerja, lead time produksi menjadi lebih pendek, kualitas produksi meningkat secara signifikan, produktivitas meningkat, dan kebutuhan akan alat-alat pendukung (tools) juga berkurang. Selain itu, juga dapat mengurangi material handling, yang biasa diakibatkan karena tata letak yang tidak tepat, mengurangi inventori, proses lebih efisien, serta dapat meningkatkan kepuasan dan moral pekerja (Wignjosoebroto, 2009).

CV. Anugerah Sukses Sejahtera adalah perusahaan yang men-supply dan juga memanufaktur produk-produk karet seal. Selama ini perusahaan belum begitu memperhatikan sistem pengaturan tata letak mesin produksi dengan tepat. Hal tersebut yang mengakibatkan proses produksi belum berjalan secara efisien. Pelayanan produksi yang dilakukan selama ini mengikuti sistem First in First Service (FIFS), dan selama 8 jam kerja per hari.
Dengan latar belakang di atas, maka perlu untuk diajukan sebuah alternatif perencanaan tata letak mesin yang sesuai, agar produksi dapat berjalan lebih efisien dan tidak mengakibatkan crash production.

\section{A. Pola Aliran Bahan}

Pada dasarnya, produktivitas suatu proses produksi dapat dicapai dengan cara mengatur aliran proses secara efektif dan efisien. Urutan proses produksi tersebut dapat diartikan sebagai aliran yang dibutuhkan untuk memindahkan posisi berbagai elemen produksi (bahan baku/material, orang, parts, dan sebagainya). Aliran proses dikelompokkan menjadi 3 tahapan, yaitu (Wignjosoebroto, 2009):

1. Perpindahan dari seluruh material dari hulu atau sumber bahan menuju ke lokasi pengolahan material

2. Perpindahan material di area proses produksi, dan

3. Seluruh aktivitas distribusi produk jadi menuju ke konsumen.

Sedangkan untuk mendukung perpindahan material tersebut pola aliran bahan sangat tergantung dari beberapa hal berikut ini :

1. Area yang tersedia

2. Dimensi lantai produksi

3. Luas area yang diperlukan untuk fasilitas produksi

Berikut ini adalah contoh dari pola aliran bahan dan kegunaannya dalam suatu proses produksi : 
a). Straight Line, umumnya digunakan jika proses produksi berjalan dengan singkat, sederhana, dan mungkin saja hanya terdiri dari beberapa peralatan produksi.

b). Zig-zag (s-shaped), digunakan untuk proses produksi yang panjang namun area produksi terbatas.

c). U-shaped, biasanya digunakan pada suatu proses dimana aliran keluar dan masuk bahan dari satu arah, yang tujuannya untuk memudahkan pengawasan.

d). Circular (O-Flow), diterapkan pada proses dimana penerimaan bahan atau material serta pengiriman barang/produk ada di titik yang sama.

Odd-Angle, digunakan pada area yang terbatas, dan proses pemindahan bahannya dilakukan secara mekanik.

\section{METODE PENELITIAN}

Aliran pelaksanaan penelitian, penerapan metode corelap, serta hasil perbandingannya dengan kondisi semula akan ditunjunkkan pada uraian di bawah ini.

A. Tahapan Perancangan Tata Letak Fasilitas

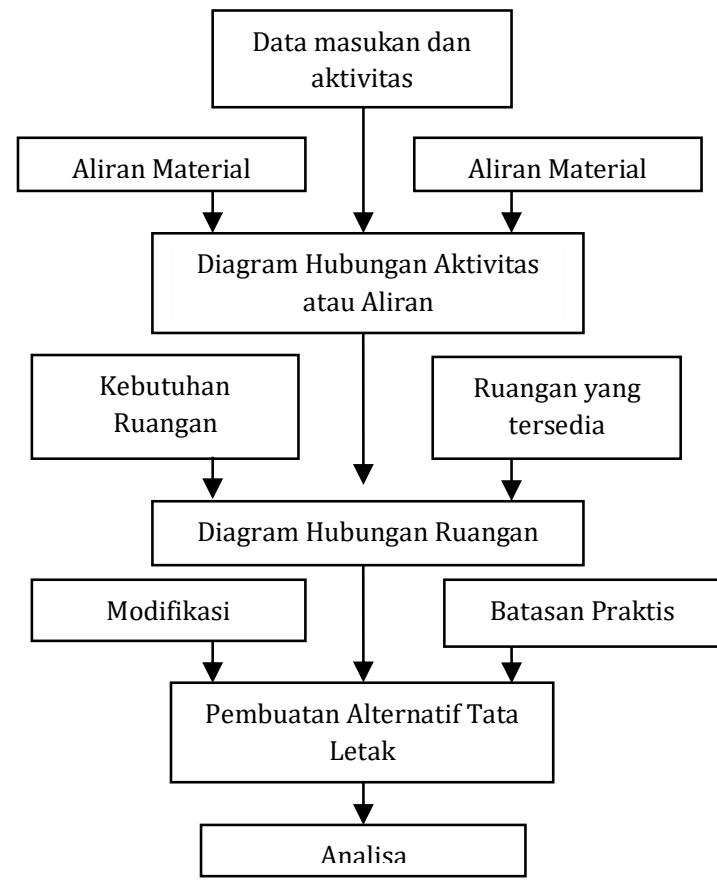

Gambar 1. Tahapan Perancangan Tata Letak Fasilitas

Tahapan Perancangan Tata Letak Fasilitas menurut (Muther, 1973) yang kemudian dikutip oleh (Oktiarso \& Loekito, 2017), tahapan-tahapan proses suatu perancangan tata letak yang dijabarkan menjadi mengikuti urutan kegiatan dengan menggunakan pendekatan Systematic
Layout Planning (SLP). Gambar 1 di atas adalah skematis prosedur pelaksanaan SLP.

B. Aliran Pelaksaan Penelitian

Berikut ini adalah gambar aliran proses pelaksanaan penelitian yang dilakukan.

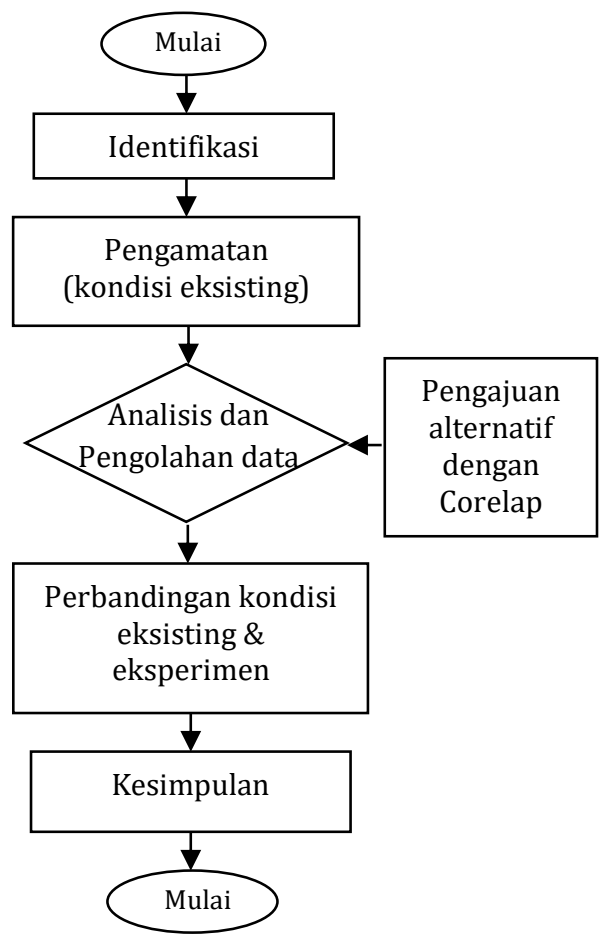

Gambar 2. Diagram alir penelitian

\section{Metode Corelap}

Metode corelap adalah sebuah metode yang digunakan untuk menghitung hubungan kedekatan suatu tata letak fasilitas berdasarkan kegiatan yang paling tinggi/sibuk dan memiliki keterkaitan yang cukup banyak dengan fasilitas yang lainnya (Apple, 1990) yang kemudian dikutip oleh (Dwianto, Susanty, \& Fitria, 2016).

Pada metode ini, akan dilakukan pembobotan berdasarkan tingkat kedekatan suatu kegiatan dengan kegiatan yang lainnya. Dimana kegiatan yang mempunyai jumlah tertinggi dan akan disebut sebagai total closeness rating (TCR) akan diletakkan pada matrik yang pertama. Dan untuk selanjutnya akan dicari kegiatan yang harus di tempatkan sedekat mungkin dengan kegiatan utama.

Nilai atau pembobotan pada metode corelap ini diberikan simbol berupa abjad sebagai bentuk kedekatan yang :
A : sangat penting
$\mathrm{U}$ : tak perlu
I : penting
$\mathrm{X}$ : tak diharapkan

0 : biasa 
Keuntungan dari penggunaan metode corelap ini, adalah dapat menentukan secara manual mengenai ketergantungan atau tingkat kebutuhan suatu kegiatan dengan kegiatan yang lain. Sehingga, dari pengaplikasian metode ini dapat ditemukan rancangan atau lay out alternatif yang tidak tergantung pada layout awal.

\section{Penelitian Terdahulu}

Ada banyak sekali peneliti yang telah melakukan pengamatan untuk menyusun tata letak fasilitas produksi. (Yuliant, Saleh, \& Bakar, 2014), mengajukan rancangan pengaturan tata letak fasilitas, namun menggunakan metode konvensional. Pada penelitian tersebut bertujuan meminimasi pengeluaran yang diakibatkan dari kegiatan material handling. Di sini juga dilakukan perbanding kondisi awal saat belum dan sudah dilakukannya eksperimen. Perbandingan difokuskan pada ongkos yang dikeluarkan dari pemindahan bahan.

(Setiawan, 2017), yang mengamati tata letak produksi kedai goring menggunakan metode Corelap. Dimana saat penelitian dilaksanakan tata letak produksi masih belum tertata dengan efisien. Seringnya terjadi back tracking di area produksi menjadi latar belakang masalah yang diangkat. Namun ketika metode corelap diaplikasikan hasilnya mengalami penurunan jarak tempuh (perpindahan bahan) tiap tahunnya.

Pada tahun yang sama (Oktiarso \& Loekito 2017) melakukan perancangan ulang tata letak area produksi menggunakan metode Systematic Plant Layout (SPL). Yang mendasari dilakukannya penelitian tersebut adalah penataan mesin yang tidak terstruktur dan mengakibatkan proses produksi menjadi semakin lama. Hasil dari penelitian tersebut adalah berkurangnya jarak total perpindahan material.

(Putra, 2018) menerapkan metode corelap untuk merancang tata letak mesin produksi di CV. Robbani Singosari, yang dilatar belakangi dengan besarnya/tingginya jarak material handling akibat dai pemindahan bahan, dan bahkan proses pemindahannya juga melewati jalur pejalan kaki. Dan hasil dari rancangan itu membuat jarak perpindahan material menurun hingga 49\%. Penurunan jarak yang cukup baik inilah yang menjadikan dasar dari pengaplikasian metode corelap pada penelitian ini.

Adapun kelebihan dari metode corelap ini adalah mempertimbangkan keterkaitan kedekatan suatu area yang dianggap paling sibuk dengan area yang lain. Pada metode corelap ini juga dilakukan pembobotan dan perangkingan dari keterkaitan kedekatan area tersebut. Dan hasilnya adalah sebuah peringkat hubungan kedekatan yang digunakan sebagai alternatif penempatan stasiun kerja.

\section{HASIL DAN PEMBAHASAN}

\section{A. Kondisi Eksisting}

Pada pengamatan pertama yang dilakukan di lokasi, didapatkan desain lay out mesin produksi seperti pada gambar berikut ini. Dari gambar tersebut menunjukkan adanya perputaran aliran bahan yang tidak beraturan. Tentu saja hal ini termasuk dalam waste time produksi.

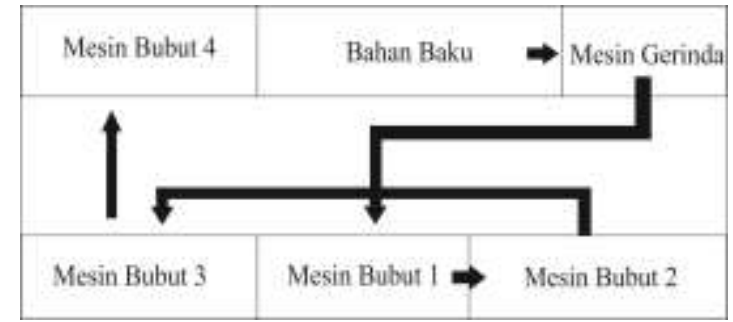

Gambar 3. Layout kondisi eksisting

\section{B. Pengajuan Layout Alternatif}

Sebelum diajukan alternatif layout aliran bahan, yang pertama dilakukan adalah menghitung jarak tempuh yang dikonsumsi pada layout semula. Jarak tempuh perpindahan bahan yang dihabiskan selama proses produksi pada kondisi ini (eksisting) mencapai 1.768 meter/bulan.

Kemudian diajukan alternatif tata letak mesin produksi menggunakan pola U Shape, dan prinsip penempatan mesinnya diperhitungkan dengan metode Corelap.

Mengapa menggunakan pola U Shape? Karena dengan pola tersebut akan memudahkan proses kontrol keluar masuk material.

\section{Pengolahan dengan metode Corelap}

Pembobotan tingkat hubungan pada metode Corelap dapat ditentukan dengan menggunakan tabel Activity Relationship Chart (ARC) (Dwianto et al., 2016).

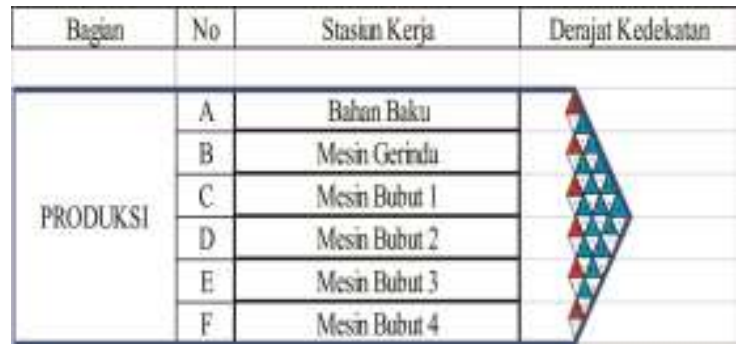

Gambar 4. ARC Lantai Produksi CV. Anugerah Sukses

Kemudian mengkonversi nilai ARC dengan nilai Total Closeness Rating (TCR), dan di dapatkan nilai seperti pada tabel 1 dan 2 berikut ini. 
Tabel 1. Perhitungan Nilai TCR

\begin{tabular}{|c|c|c|c|c|}
\hline No & $\begin{array}{c}\text { Stasiun } \\
\text { Awal }\end{array}$ & $\begin{array}{c}\text { Stasiun } \\
\text { Tujuan }\end{array}$ & $\begin{array}{c}\text { Kode } \\
\text { ARC }\end{array}$ & $\begin{array}{c}\text { Nilai } \\
\text { TCR }\end{array}$ \\
\hline 1 & A & B & a & 5 \\
\hline 2 & B & C & a & 5 \\
\hline 3 & C & D & a & 5 \\
\hline 4 & D & E & a & 5 \\
\hline 5 & E & F & a & 5 \\
\hline 6 & F & - & a & 5 \\
\cline { 4 - 5 } & & & Total & 30 \\
\cline { 4 - 5 } & & & \multicolumn{2}{l}{}
\end{tabular}

Tabel 2. Nilai TCR Seluruh Stasiun Kerja pada Lantai Produksi

\begin{tabular}{|c|c|c|c|c|c|c|c|c|c|c|c|c|c|c|}
\hline $\mathbf{i} / \mathbf{j}$ & $\mathbf{A}$ & $\mathbf{B}$ & $\mathbf{C}$ & $\mathbf{D}$ & $\mathbf{E}$ & $\boldsymbol{F}$ & $\begin{array}{c}\text { Luas } \\
(\mathbf{m} 2)\end{array}$ & A & E & I & $\mathbf{0}$ & U & X & TCR \\
\hline A & & A & O & 0 & 0 & 0 & 9 & 1 & 0 & 0 & 4 & 0 & 0 & 13 \\
\hline B & A & & A & 0 & 0 & 0 & 9 & 2 & 0 & 0 & 3 & 0 & 0 & 16 \\
\hline C & O & A & & A & 0 & 0 & 9 & 2 & 0 & 0 & 3 & 0 & 0 & 16 \\
\hline D & 0 & 0 & A & & A & 0 & 9 & 2 & 0 & 0 & 3 & 0 & 0 & 16 \\
\hline E & 0 & 0 & 0 & A & & A & 9 & 2 & 0 & 0 & 3 & 0 & 0 & 16 \\
\hline F & 0 & 0 & 0 & 0 & A & & 9 & 1 & 0 & 0 & 4 & 0 & 0 & 13 \\
\hline & & & & & & Total & & & & & & & 90 \\
\hline
\end{tabular}

D. Perhitungan dengan Corelap

Iterasi 1

Departemen A sebagai pusat, Penempatan departemen B. Hubungan kedekatan antara departemen A-B adalah A.

\begin{tabular}{|l|l|l|}
\hline 2 & 3 & 4 \\
\hline 1 & A & 5 \\
\hline 8 & 7 & 6 \\
\hline
\end{tabular}

Gambar 5. Perhitungan Algoritma CORELAP Iterasi Ke-1

Jika departemen B dialokasikan di :

Lokasi 1, 3, 5, 7 bernilai : 5

Lokasi 2, 4, 6, 8 bernilai : 0,5 x $5=2,5$

Maka departemen $\mathrm{B}$ ditempatkan di lokasi no 1.

\begin{tabular}{|c|c|c|}
\hline 8 & 7 & 6 \\
\hline B & A & 5 \\
\hline 2 & 3 & 4 \\
\hline
\end{tabular}

Gambar 6. Hasil Perhitungan Algoritma CORELAP Iterasi Ke-1

Iterasi dilakukan sampai semua stasiun kerja selesai diploting.

$\underline{\text { Iterasi } 2}$

Penempatan departemen C. Hubungan kedekatan antara departemen A-B adalah A, dan antara departemen A-C adalah 0 .

\begin{tabular}{|c|c|c|c|}
\hline 10 & 9 & 8 & 7 \\
\hline C & B & A & 6 \\
\hline 2 & 3 & 4 & 5 \\
\hline
\end{tabular}

Gambar 7. Hasil Perhitungan Algoritma CORELAP Iterasi Ke-2

$\underline{\text { Iterasi } 3}$

Penempatan departemen D. Hubungan kedekatan antara departemen D-A adalah 0 , antara departemen D-C adalah A, dan antara D-B adalah 0.

\begin{tabular}{|c|c|c|c|c|}
\hline 12 & 11 & 10 & 9 & 8 \\
\hline 1 & $\mathrm{C}$ & $\mathrm{B}$ & $\mathrm{A}$ & 7 \\
\hline 2 & $\mathrm{D}$ & 4 & 5 & 6 \\
\hline
\end{tabular}

Gambar 8. Hasil Perhitungan Algoritma CORELAP Iterasi Ke-3

$\underline{\text { Iterasi } 4}$

Penempatan departemen E. Hubungan kedekatan antara departemen E-C adalah O, antara departemen E-B adalah O, antara departemen E-A adalah $\mathrm{O}$, dan antara departemen E-D adalah A.

\begin{tabular}{|c|c|c|c|c|}
\hline 14 & 13 & 12 & 11 & 10 \\
\hline 1 & C & B & A & 9 \\
\hline 2 & D & E & 7 & 8 \\
\hline 3 & 4 & 5 & \multicolumn{2}{|c}{} \\
\cline { 1 - 3 } & &
\end{tabular}

Gambar 9. Hasil Perhitungan Algoritma CORELAP Iterasi $\mathrm{Ke}-4$

Pada penelitian ini, iterasi dilakukan sebanyak 5 kali, dan hasil dari iterasi ke 5 adalah sebagai berikut :

\section{$\underline{\text { Iterasi } 5}$}

Penempatan departemen F. Hubungan kedekatan antara departemen F-A adalah $\mathrm{O}$, antara departemen F$\mathrm{E}$ adalah $\mathrm{A}$, antara departemen E-D adalah $\mathrm{O}$, antara departemen E-C adalah O, dan antara departemen E-B adalah 0 .

\begin{tabular}{|c|c|c|c|c|}
\hline 14 & 13 & 12 & 11 & 10 \\
\hline 1 & C & B & A & 9 \\
\hline 2 & D & E & 7 & 8 \\
\hline 3 & 4 & 5 & 6 & \multicolumn{1}{|c}{} \\
\cline { 1 - 3 } & & &
\end{tabular}

Gambar 10. Perhitungan Algoritma CORELAP Iterasi Ke-5 
Jika departemen $\mathrm{F}$ dialokasikan di :

Lokasi 1 bernilai : $2+(0,5 \times 2)=3$

Lokasi 2 bernilai : $2+(0,5 \times 2)=3$

Lokasi 3 bernilai : $0,5 \times 5=2,5$

Lokasi 4 bernilai : $2+(0,5 \times 5)=4,5$

Lokasi 5 bernilai : $2+(0,5 \times 2)=3$

Lokasi 6 bernilai : $(0,5 \times 5)+2=4,5$

Lokasi 7 bernilai : $(0,5 \times 5)+5=\mathbf{7 , 5}$

Lokasi 8 bernilai : $0,5 \times 2=1$

Lokasi 9 bernilai : $(0,5 \times 2)+2=3$

Lokasi 10 bernilai : $0,5 \times 5=2,5$

Lokasi 11 bernilai : $2+(0,5 \times 2)=3$

Lokasi 12 bernilai : $2+(0,5 \times 2)=3$

Lokasi 13 bernilai : $2+(0,5 \times 2)=3$

Lokasi 14 bernilai : $(0,5 \times 5)=2,5$

Maka departemen E ditempatkan di lokasi no 7.

Setelah semua stasiun kerja ditempatkan, maka iterasi telah selesai. Bentuk akhir dari perancangan layout dengan menggunakan algoritma CORELAP adalah sebagai berikut

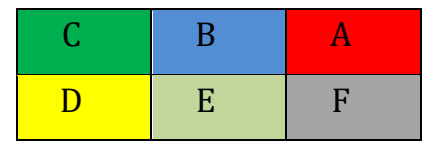

Gambar 11. Hasil pengolahan corelap

Total momen perpindahan pada tiap stasiun kerja di lantai produksi setelah menggunakan Metode Algoritma Corelap ditunjukkan pada Tabel 3 di bawah ini.

Tabel 3. Total Momen Perpindahan Material Antar Stasiun Hasil Dari Iterasi Algoritma CORELAP

\begin{tabular}{|c|c|c|c|c|c|}
\hline No & $\begin{array}{c}\text { Stasiun } \\
\text { Awal }\end{array}$ & $\begin{array}{c}\text { Stasiun } \\
\text { Tujuan }\end{array}$ & $\begin{array}{c}\text { Frekuensi } \\
\text { Perpindahan } \\
\text { (Kali) }\end{array}$ & $\begin{array}{c}\text { Jarak } \\
\text { Stasiun } \\
\text { (m) }\end{array}$ & $\begin{array}{c}\text { Momen } \\
\text { Perpindahan } \\
\text { (m/bulan) }\end{array}$ \\
\hline 1 & A & B & 52 & 3 & 156 \\
\hline 2 & B & C & 52 & 3 & 156 \\
\hline 3 & C & D & 104 & 3 & 312 \\
\hline 4 & D & E & 104 & 3 & 312 \\
\hline 5 & E & F & 104 & 3 & 312 \\
\hline 6 & F & - & 0 & 0 & 0 \\
\hline
\end{tabular}

E. Perbandingan layout kondisi Eksisting dengan Eksperimen (corelap)

Perbandingan yang dilakukan di sini melibatkan 3 variabel pendukung, antara lain : Alur Produksi, Momen perpindahan, dan kemudahan komunikasi antar stasiun kerja. Pada tabel 4 berikut menunjukkan hasil perbandingan dari dua kondisi yang berbeda di lantai produksi.

Tabel 4. Perbedaan hasil layout produksi

\begin{tabular}{|c|c|c|}
\hline & Kondisi eksisting & $\begin{array}{c}\text { Kondisi } \\
\text { eksperimen } \\
\text { (aplikasi } \\
\text { metode } \\
\text { Corelap) } \\
\end{array}$ \\
\hline $\begin{array}{l}\text { Alur } \\
\text { Produksi }\end{array}$ & $\begin{array}{l}\text { - Tidak efektif } \\
\text { - Menimbulkan } \\
\text { crash production }\end{array}$ & 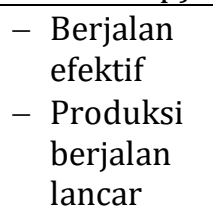 \\
\hline $\begin{array}{l}\text { Momen } \\
\text { perpind } \\
\text { ahan }\end{array}$ & 1.768 meter/bulan & $\begin{array}{l}1.248 \\
\text { meter/bulan }\end{array}$ \\
\hline $\begin{array}{l}\text { Kemuda } \\
\text { han } \\
\text { komunik } \\
\text { asi }\end{array}$ & $\begin{array}{l}\text { Terjadi kesulitasn } \\
\text { berkomunikasi } \\
\text { dengan stasiun } \\
\text { kerja yang akan } \\
\text { dituju. }\end{array}$ & Lebih mudah \\
\hline
\end{tabular}

\section{PENUTUP}

Dari penelitian dan analisis perhitungan di atas dapat disimpulkan bahwa penerapan metode Correlap pada lantai produksi di CV. Anugerah Sukses Sejahtera dapat memberikan perubahan yang lebih baik. Dengan berkurangnya momen perpindahan, maka dapat dipastikan waktu produksi akan menurun dan crash production dapat dihindari.

\section{DAFTAR PUSTAKA}

Dwianto, Q. A., Susanty, S., \& Fitria, L. (2016). Usulan Rancangan Tata Letak Fasilitas Dengan Menggunakan Metode Computerized Relationship Layout Planning (CORELAP) di Perusahaan Konveksi. REKA INTEGRA, 4(1).

Muther, R. (1973). Systematic Layout Planning/by Richard Muther.

Oktiarso, T., \& Loekito, H. S. (2017). PERANCANGAN ULANG TATA LETAK AREA PRODUKSI PT $X$ DENGAN METODE SYSTEMATIC PLANT LAYOUT. Prosiding SENIATI, 3(2), 51-53.

Putra, Y. P. (2018). MERANCANG TATA LETAK FASILITAS PABRIK DENGAN METODE ALGORITMA CORELAP DI CV. ROBBANI SINGOSARI. Jurnal Valtech, 1(1), 65-70. 
RAJAMANI*, D., Singh, N., \& Aneja, Y. P. (1996). Design of cellular manufacturing systems. International Journal of Production Research, 34(7), 1917-1928.

Setiawan, B. S. A. D. (2017). HUBUNGAN KELELAHAN TERHADAP KINERJA SUPIR DUMP TRUCK PT RAYA BUMI MANDIRI SAMARINDA.
Wignjosoebroto, S. (2009). Tata letak pabrik dan pemindahan bahan. Surabaya: Guna Widya.

Yuliant, R., Saleh, A., \& Bakar, A. (2014). Usulan Perancangan Tata Letak Fasilitas Perusahaan Garmen CV. X dengan menggunakan Metode Konvensional. REKA INTEGRA, 2(3). 